\title{
Some areal features of the 110 -item wordlist for the Indo-Aryan languages of South Odisha ${ }^{1}$
}

\begin{abstract}
In this paper, I discuss the issue of replacement of basic lexicon due to language contact, specifically focusing on Indo-Aryan, Dravidian, and Munda languages in South Odisha but with implications for Eastern India as a whole. Apart from direct borrowings, special attention is paid to cases of not particularly obvious substrate influence in Indo-Aryan languages, in which inherited lexicon is substituted by other inherited items as a result of semantic shift typical of a neighbouring language family. This type of phenomena should necessarily be taken into consideration in any quantitative studies involving lexicostatistical calculations.
\end{abstract}

Keywords: Indo-Aryan languages; Dravidian languages; Munda languages; basic lexicon; lexicostatistics; areal linguistics.

The aim of this study is to describe a number of specific features of the basic vocabulary contained in the 110-item Swadesh/Starostin/Yakhontov wordlists in the context of an entire language area (Sprachbund), primarily focusing on the data of the micro-language-area of South Odisha (India) and its position within a larger area - East India as a whole (in the text below I shall refer to East India as a mini-area, since the term 'area' would be more suitable to describe the entirety of South Asia as a whole). In these regions, three different language families are represented: Indo-Aryan, Dravidian, and Munda. Speakers of these languages are all settled in adjacent locations, where different language idioms mutually influence each other.

The importance of studying the history of basic vocabulary, such as the 110-item word list, in the context of a language area, stems from the following reasons: 1) the list contains basic vocabulary that is, as a rule, least affected by semantic change and lexical replacement; 2) its items are commonly used in glottochronology to estimate the approximate date of splitting of different language idioms.

According to one methodology of lexicostatistical evaluation of the degrees of genetic relationship between different languages, developed by Sergei Starostin and commonly employed in the Moscow School of comparative linguistics, borrowings from other languages should not be taken into account for such an evaluation, since the number of borrowed words can drastically surge during periods of intensive language contacts, whereas replacement of words from the basic wordlist with other indigenous words is assumed to proceed at a more or less regular rate, independently of language contacts. My goal here is to investigate the possibility of lexical replacement in the basic wordlist with original words from the inherited lexical stock that is nevertheless still driven by language contact.

Although the language map of South Asia (Fig. 1 in the Supplement) shows languages from a variety of genealogical groups, my research concerns only three language families: Indo-Aryan, Dravidian, and Munda. The Indo-Aryan languages are spread throughout the

1 This research has been supported by the Russian Foundation for Basic Research, project 17-34-00018: "Sociolinguistic research of the Koraput Munda languages and development of a multimedia corpus of texts exemplifying different social conditions of language usage”.

Journal of Language Relationship • Вопросы языкового родства • 17/4 (2019) • Pp. 285-296• ( ) The authors, 2019 
Northern part of the subcontinent, while the southern part is largely occupied by Dravidian languages. In the north, Dravidian languages are represented by two isolated areas: Brahui in the west, Kurukh and Malto in the East. The Munda languages, belonging to the AustroAsiatic family, are spoken in three isolated regions: border areas of the states of Odisha, Jharkhand and West Bengal in the north, the border of Odisha and Andhra Pradesh states in the south, and the border of Madhya Pradesh and Maharashtra states in the west. Archaeological and historical linguistic data allow us to assume that Dravidian and Munda languages may have occupied much larger territories in the past.

We collected data on the languages of the South Odisha micro-area during field trips to Odisha in between 2016-2018². Different datasets were collected, but one of our specific tasks was to assemble 110-item wordlists of basic lexicon. As far as possible, those lists were put together according to the specifications of semantic contexts proposed in Kassian et al. 2010, Dybo 2013.

The languages studied in this paper include ${ }^{3}$ :

1) Munda, including two dialects of Sora, two dialects of Bonda, Didayi, Gutob, Ho and Mundari;

2) Dravidian, including Koya and Kui;

3) Indo-Aryan languages and dialects, including Desiya, Pano (two dialects), Oriya, Bengali, Assamese, Hindi, Punjabi, Lahnda, Sindhi, Rajasthani, Mewati, Gujarati, Marathi, Konkani, Kullui, Garhwali, Kumaoni, Nepali, Braj, Awadhi, Maithili.

Since my research is chiefly focused on Odisha, I need to provide some explanations regarding the idioms of this state, and specifically of South Odisha (Fig. 2 in the Supplement). Sora, whose dialectal diversity has so far not been studied in sufficient detail, is represented by Lanjiya and Sarda dialects. Of these, Lanjiya is the most popular idiom and has been extensively studied by the majority of researchers; we, however, take into account the importance of materials from other dialects as well, primarily Sarda. Lanjiya is spread in Gajapati district and Sarda belongs to Rayagada district.

Bonda is spread in the Malkangiri district. We have collected data on the Lower and Hill dialects, of which the Lower or Plain Bonda is more influenced by widespread languages than Hill Bonda. Didayi is also located in the Malkangiri district; Gutob is native to the Koraput district. All of these belong to the South Munda group. Ho and Mundari languages belong to the Kherwarian subgroup of the Northern Munda group and are spread in several northern districts of Odisha and some districts of Jharkhand.

Of the Dravidian languages, Kui is situated in the Kandamahal district and Koya is a dialect of Gondi spoken in the Malkangiri district.

Finally, of the Indo-Aryan languages, Oriya is the state language of Odisha, belonging to the Eastern group. Desiya and Pano are colloquial idioms, close to Oriya. Existing literature on Desiya is extremely scarce. It is a lingua franca for communication between caste groups and tribes in the districts of Koraput and Malkangiri. It is widely believed to be a pidgin rather than a native language for any of the caste groups and tribes living there. However, according

2 I have to acknowledge here Evgeniya Renkovskaya, my constant companion and colleague, without whom this work would not be possible, for participating in the collection of data and for her sharp insights on the subject.

3 The wordlists for Sora, Bonda, Didayi, Gutob, Ho, Mundari, Kui, Koya, Kullui, Oriya and Bengali languages were collected during our field trips in 2014-2018. For other Indo-Aryan languages (Hindi, Punjabi, Lahnda, Sindhi, Rajasthani, Mewati, Gujarati, Marathi, Konkani, Garhwali, Kumaoni, Nepali, Braj, Awadhi, Maithili) we have used the lists from Kogan 2016, with corrections made in Krylova 2017. 
to our field data, this is not the case, since there are influential castes, such as the Rona, for which Desiya is native at the moment. Nowadays, the Gutob tribe is switching to Desiya, and rapidly losing its native language. As for the Pano idiom, no one has ever studied it properly. It is spoken by a large caste group in the districts of Gajapati and Rayagada, adjacent to the Sora language (they are spoken next to each other in many villages). It is closer to Oriya than Desiya, but its wordlist still has some significant differences.

According to historical evidence by Piers Vitebsky (2017), during the period when most of the Sora people were monolinguals the Pano caste group occupied the niche of interpreters in the communication between Sora and Oriya-speaking government officials. In communications between the officials of Koraput and local tribes, the main language in use is Desiya, and Desiya-speaking interpreters play a key role, since most of the tribal population speaks Desiya, but not Oriya. From this point of view, Pano and Desiya are in similar positions. We have assembled two 110-item wordlists in the Pano language from the Gajapati and Rayagada districts, because it was not previously clear how the two Pano dialects differ from each other, especially since in two different districts, speakers of Pano language are neighbours to speakers of two different Sora dialects. As for the other Indo-Aryan languages taken into account, I have included these to provide a broader base of comparison.

Variations in basic vocabulary under the influence of language contacts (as in the case of the specified areas) may be traced through borrowings, partial borrowings and replacements of some original words by others (including replacements from inherited vocabulary) under the influence of language contacts. The most obvious example of mutual influence between languages in the vocabulary is, of course, direct borrowing. In the area of intensive language contact, the number of borrowings may be very significant even in the basic vocabulary. For example, I found 18 clear loanwords from the Indo-Aryan and 7 from the Dravidian family in the Munda languages of South Odisha; two Dravidian languages include 20 Indo-Aryan and 1 Munda loanwords; and in the Indo-Aryan idioms of the mini-area, 10 Dravidian and 2 Munda words were discovered. Borrowings from Indo-Aryan languages in Dravidian and Munda are more numerous than borrowings from Dravidian to Munda. Overall, the main source of borrowing is predictably identified as the Indo-Aryan languages; next in frequency are the Dravidian languages, while the contribution of Munda is insignificant.

Indo-Aryan loanwords in Kui: kali 'black', raka 'blood', puri 'full', loku 'person', coka 'round', balu 'sand', bela 'sun', dhuali 'smoke', poheri 'swim', jorek 'two', duru 'far', basari 'year'.

Indo-Aryan loanwords in Koya: Koya soben 'all', padaך 'foot', manei 'man', mansun 'man',

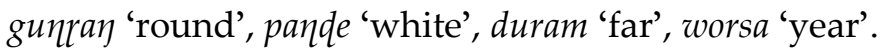

Indo-Aryan loanwords in Munda languages of the South Odisha: Sora sana 'small', Bonda kaliya 'black', Gutob kakor 'cold', Gutob bosa 'fat', Gutob urei 'fly', Gutob jibon 'heart', Gutob manus 'person', Gutob besi 'many', Gutob roy 'red', Gutob jorek 'two', Gutob tati 'warm', Didayi tara 'star', Bonda, Didayi borti 'full', Bonda, Didayi bol 'good', Gutob, Didayi buk 'breast', Bonda, Didayi patla, Gutob potla 'thin', Bonda borso, Didayi, Gutob boros 'year'.

Dravidian loanwords in Munda languages of the South Odisha: Sora kob/kumab 'ashes', Gutob poyrei 'swim', Didayi dula 'lie, sleep', Bonda piri, Gutob piri 'bird', Didayi, Gutob chendi 'hair', Sora, Bonda, Didayi, Gutob maๆdi 'knee', Bonda, Didayi monji 'seed'.

Munda loanwords in Kui: gule 'all'.

Dravidian loanwords in Eastern Indo-Aryan languages: Desiya gar 'egg', chendi 'hair', maṇdi 'knee', dul- 'lie', Desiya, Pano cher 'root', Desiya, Pano (Gajapati) andra 'man', Pano (Gajapati) sok 'neck', gundiya 'heart', Oriya, Pano, Desiya monji 'seed', Oriya, Assamese, Bengali kāmur- 'bite'. 


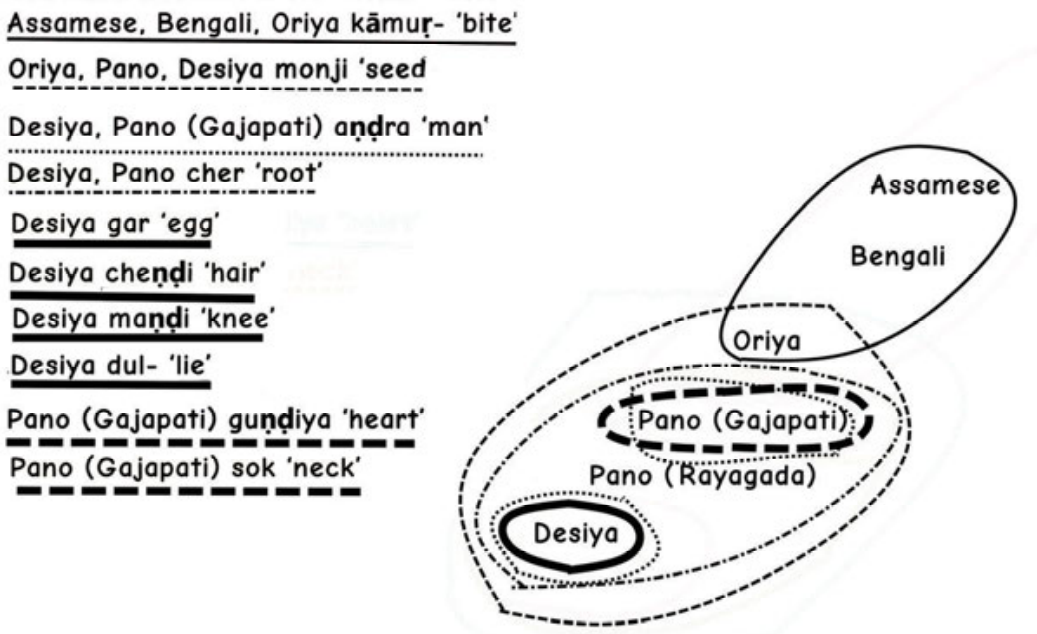

Figure 3. Dravidian loanwords in East Indo-Aryan languages

Figure 3 illustrates the spread of Dravidian borrowings across the 110-item wordlists of Eastern Indo-Aryan languages. It clearly shows that their number reaches its maximum in South Odisha.

\section{Assamese}

Bengali

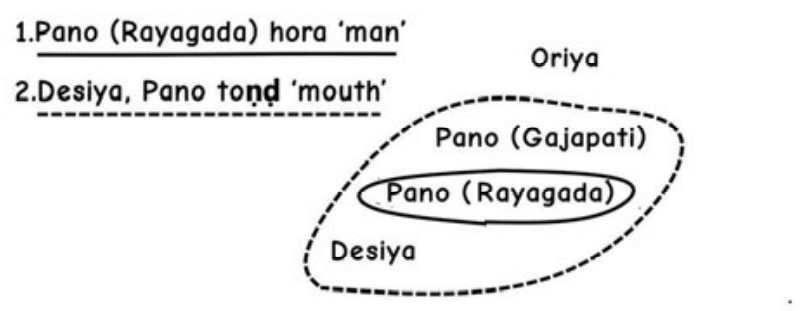

Figure 4. Munda loanwords in East Indo-Aryan languages

Borrowings from Munda to Indo-Aryan are much fewer in number: Pano (Rayagada) hora 'man' and Desiya, Pano tond 'mouth'. Here it is quite instructive to pay special attention to the latter. This root is widely represented in IA languages, and, according to Turner 1966, it had already been borrowed into Proto-Indo-Aryan:

5853 tuṇda n. 'beak, trunk, snout' TĀr. MBh., 'contemptuous term for mouth’ Bādar, túndika 'having a trunk' AV. [Cf. trōṭi f. 'beak, fish's mouth’ lex., and further śuṇd̄a, cañcu, *cōṇta. Cert. non Aryan and prob. $\leftarrow$ Mu. EWA i 510. Poss. same as tundi 'navel' and tundá 1 'belly' with which it shares several variant forms. Some of these may be due to differences of dialect in the source language, some to phonetic development within IA. (e.g. $t+t>t t)$, some to slang deformation]

1. tunda: Pa. tunda, ’aka n. 'beak, mouth, snout'; Pk. tumida n., ’d̄ f. 'mouth, front part'; S. tunī f. 'spout'; Or. tunda 'lips, mouth, beak', tundi 'muzzle', (Sambhalpur) tũd 'mouth', M. tũd n.; Si. tuda 'beak, snout, mouth'. 2. *tuda: Si. tola (st. tol ) 'lip', tolu gānavā 'to graze (lit. rub the lips on)'. 3. *tōnda: Pk. tomda n. 'mouth, front part'; M. tõd m. 'mouth', Ko. toịḍa. 4. *tōtța 1: Or. toți 'throat'; M. toțī f. 'spout'. 5. *tōnta: K. tõth (dat. 'ti) f.

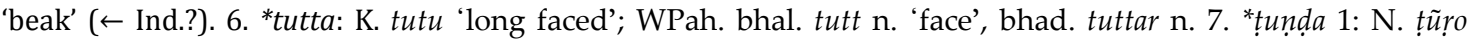
'mouth of animal, beak, point of ploughshare'; Or. (Jānpur) țunda 'lips, mouth, beak'; Bi. țưr, 'r $r \bar{a}$ 'beard of wheat' (semant. cf. sũr s.v. śuṇ̣ā 1). 8. *tunțta 1: A. țũțli 'fleshy protuberance under chin'; B. țũți 'throat'.

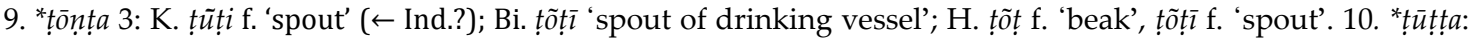




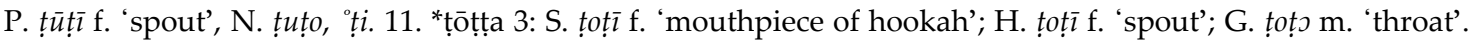
12. *thuṇda: L. thunn m. 'thick lips (opprobrious term)', awāṇ. thun 'lips'. 13 *thuntha: A. thũtari 'chin', B. thũti, thũtani; Or. thũti 'chin, snout'. 14. *thuttha: P. thūthn̄ā m., thū thṇ̄ f. 'mouth of horse or camel'; N. thutunu 'nose, snout'; A. thutari 'chin'; B. thuti, thutani 'chin, mouth of animal'; Or. thuthi, 'ti 'snout, chin, beard'; Bhoj. thuthun 'pig's snout'; Mth. thūthun 'mouth of animal'; Aw.lakh. thūthun 'horse's nostrils'; H. thüthrāa, thūthan, thūthnā m. 'snout, mouth'. 15. *thōda 1: Or. thori 'lower lip, chin, beard'. 16. *thōdda: L.mult. thod m. 'lip', (Ju.) thod m., thod̦ $\mathrm{i}$ f. 17. *thōttha 1: Mth. thothī 'mouth'; H. thoth m. 'snout', thotī f. 'forepart of animal's face'; M. thotrī, thodrī f. 'side of cheek'. 18. *thōntha 1: B. thõtā 'chin'. 19. *thēnțha 1:

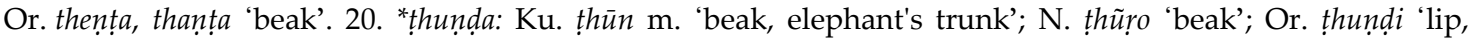

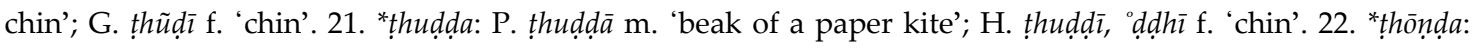

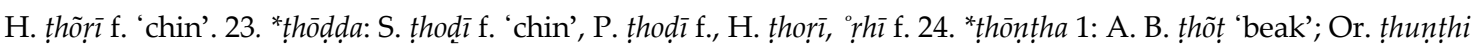
'lip, chin, beak'; Mth. H. țõth f. 'beak'. 25. *duṇda: L.mult. dunn, (Ju.) dun m. 'wild pig's snout'. 26. *ḍunda 1: K. dọ̆ndu m. 'front of face'. 27. *dutta: Dm. dut 'lip'; Woț. dut f. 'mouth'; Bshk. dut 'lip' (Leech "dùdh" < *duddha

?), Tor. dūt; Phal. dut 'mouth' (dhut<*dhutta ?); Sh.pales. dūt 'lip'. Forms with $r$ (cf. trōti f. 'beak' lex.) in Sh.koh. turūṭi 'lip', jij. thurūṭi, gil. thŭrū'țŭ m. 'beak' (Turner 1966: 334).

In Munda languages, the root is well represented and can be traced back to the ProtoAustro-Asiatic level:

393. Kh to'mo'd 'Mund (mouth)', Ju tamar, tamon(i), tomor, Gu tummo:, PaV tovo:, Re to:m- (KF), Pa to:t,

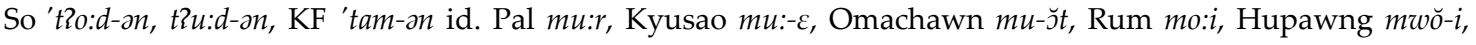
Pangnim mot 'mouth', Khm măt (meât) 'bouche, gueule, bec', Sem. Jur. New. temut, U. Cher, to-nut, Sem. Beg. lănud, Sem. Martin tenót. U. Tem. ka-n-ut, Or. Hu. Joh. II. snut, U. Ind. nut 'mouth' usw. (Pinnow 1959: 178).

$1001{ }^{*} t^{1} a t$ 'mouth'. A: (Khmer, Palaungic, Aslian) Jehai tanad, Semnam tani:d, Semaq Beri kanut; (" $\left.t^{1} m a t>\right)$

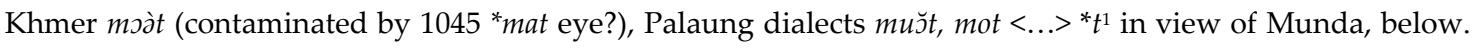
$<\ldots>$ Sora 't?o:d-an, 't?ud-an, \&c., Kharia to'mo'd, \&c. (Shorto 2006: 287).

Evidently, this word has to be considered as primordial for the East Indo-Aryan level. However, as a rule, in modern Aryan languages it is represented in less basic meanings, such as, 'bird's beak'. In the basic meaning 'mouth', it replaces the descendants of Old Indo-Aryan mukha in southernmost Odisha and, apparently not coincidentally, also in Marathi (tõ d 'mouth'), which is in contact with the area where Korku is spoken. Two explanations are plausible: 1) a secondary loanword in New Indo-Aryan languages; 2) as a result of semantic shift, Common Indo-Aryan mukha 'mouth' was replaced by descendants of Proto-Indo-Aryan tunda 'beak, trunk, snout' under the influence of neighbouring Munda languages.

\section{Partial borrowing}

Partial borrowings are rare in basic vocabulary, and are more likely to represent isolated cases, though they do occur. See, i.e. Gutob pad susuy 'foot', formed from Desiya pad 'foot' and Gutob

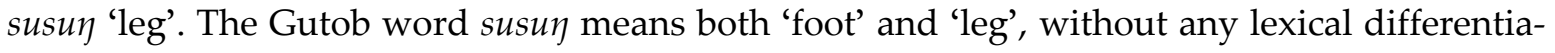
tion of the two meanings. In Desiya (and Oriya) they are expressed by different words: pad ( $p$ do) 'foot', god 'leg'. Thus, areal influence can lead to splitting of previously inseparable meanings and to partial borrowing.

Original words that replace basic lexicon under the influence of language contact

As stated in Normanskaya 2005: 148-149, the colour designation system in the Vedic language did not transparently distinguish between 'green' and 'yellow'. The words pita-, pittaka were used for 'yellow', whereas hári-, hariná, harit-, harita-, haritála could be used for both 'yellow' and 'green'. 
For the Proto-Indo-Aryan language this is apparently not the case. In Sanskrit, the adjective pitala in the meaning 'yellow' is not fixed in texts, but is indicated only in lexicographical works. However, it is from this word that items with the basic meaning 'yellow' (included in the 110-item wordlists of the majority of Indo-Aryan languages) have developed:

8233 pitala 1 'yellow' lex. 2. *pīthala - . 3. *pīvala 4. *pīvada - . [pītala(ka) n. 'brass' lex. pittala 2: see pittá, pìta 2]

1. Pk. pīala 'yellow', Ap. pīara, Paš.ar. piā’lo, dar. pếla, Woț, pyēl (m. and f.), Gau. pīlū, Sh.pales. pì'lo, S. piaro, L. P. pìlā (P. also pillā 'pale, yellow'), B. pilā, Or. pilāi Bi. pīar, piarā 'yellow (of cattle)', pìyar, piyarā 'half fired brick', (Shahabad) pìyar 'gram with yellow pointed grain'; Mth. pīar 'yellow', pìrī 'yellowness', Bhoj. pìlā adj., OAw. piyari sb., lakh. piar adj., H. pìlā, OMarw. pīla, G. pīlũ adj., püyal, pül $i$ f. 'painting women's foreheads esp. with red' (whence pĭlvũ 'to colour yellow, to dirty'). Bshk. pála 'blue, green' (AO viii 307) rather < palitá or *palva.

2. Gaw. phialá 'yellow', Sv. phyaló, Ku. pīhālo, pĩhalo, N. pa(h)ẽlo; Tor. pihīl 'green' (but AO viii 307 doubts).

3. Pk. (Deśīn.) pīvala 'yellow'; Ku. pyūlī 'a small wild flower', pyuraṛī 'a small yellow bird'; B. piuli 'yellow colour, the flower Hypericum cernuum'; Or. piuḷi 'yellow', M. pivẹ̄a

4. B. piuri 'yellow tawny colour'; Or. piuri 'yellow'.

*pītalatvanā ; *pītalavarṇa.

pītala 2 'brass' see pittala 2.

Addenda: pītala 1. 1. S.kcch. pìro 'yellow'.

3. *pīvala: WPah.kṭ. (kc.) piulı ‘yellow', J. pyũ

While in Sanskrit hari means both 'yellow' and 'green', the basic adjective 'green' in most Indo-Aryan languages originates from its derivative harita. The meaning is more or less stable (if we exclude Dardic languages and Rigveda):

13985 hárita 'yellow’ RV., 'green’ Siś., haritaka ‘greenish’ MW., n. 'vegetable matter’ Car. 2. hārita 'green' W., 'taka n. 'vegetable matter' lex. [hári ]

1. Pa. harita 'green, fresh'; Pk. hariya 'green'; Kal. (Leitner) "harílek" 'green', rumb. hā'rila 'brass', urt. harī'ra (or < hārita ?); S. haryo 'fresh and green, luxuriant'; P. hariā, harā 'green'; WPah.jaun. harō 'verdant'; Ku. hariyo, haro 'green', N. hariyo; B. hariyā 'meat curry'; Or. harā 'green', OAw. harī (pl. m. hare), lakh. harā (hariab ‘to become green'); H. hariyā, harā 'green', OMarw. harīyaü, G. haryũ, harũ. (Turner 1966: 809)

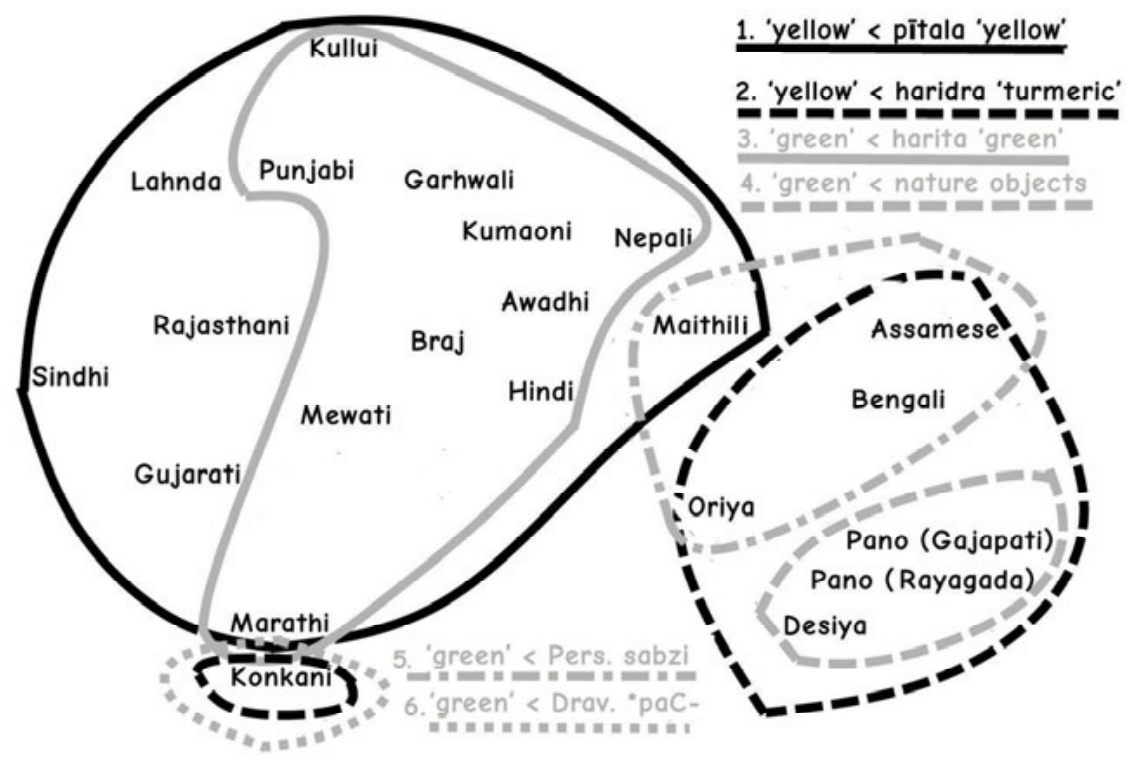

Figure 5. Origin of the basic words for 'yellow' and 'green' from Indo-Aryan languages 
Fig. 5 illustrates the origin of basic words for 'yellow' and 'green' from the 110-item wordlists in Indo-Aryan. We can see that isoglosses for the descendants of pitala and harita for the most part embrace the Indo-Aryan area, but do not reach over to Eastern India. In Eastern Indo-Aryan languages, yellow is derived from the words for 'turmeric' (Proto-Indo-Aryan haridra): Bengali holud, Assamese halodhiya, Oriya haladiā, Pano holdiya and Desiya oldi. The same

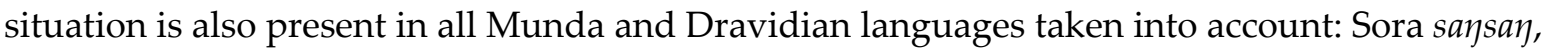

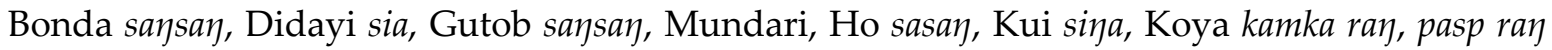
(with the loanword ray 'colour' as the second element).

Outside Eastern India, among Indo-Aryan languages the form halduve 'yellow' is related to 'turmeric' in Konkani, which is in close contact with the Dravidian languages.

As for the colour 'green', it is borrowed from Persian sabz 'green' in the north of Eastern India: Bengali šsbuj, Assamese xeuj, Oriya sabujā, Maithili sabuj. In the south of Odisha, this colour designation is primarily associated with various natural objects. The colour prototype is taken from: (a) 'leaf': Pano potro kolor, Gutob, Didei ola kolor, Koya aak ray; (b) 'a kind of weed or moss': Desiya jogliya, Sora kului, Mundari, Ho gaded, Kui jiven (meanings given by Sidwell 2009-2011). As for Konkani, pācve 'green' here is a loan from Dravidian.

A strong connection of 'yellow' with 'turmeric' (also called curcuma and Indian saffron) is observed in Dravidian languages, cf.: Proto-South Dravidian *arisana- 'saffron; yellow', ProtoSouth Dravidian *manžal 'yellow, turmeric', Proto-Gondi-Kui *sirin- 'yellow, saffron' (Starostin 2006).

The same connection is also present in the Austroasiatic language family, cf.:

1052 *rmit; *rmiit; *rmiat Curcuma species; yellow. A: (South Bahnaric, Mon, Khasi) Mon mit turmeric, ProtoNyah Kur ${ }^{*} m u t<\ldots>$, Sre ramit greenish- yellow, Chrau ramut yellowish, Biat rmut saffron $(\rightarrow$ Stieng ramat?), (or B) Khasi lmit-lmit rather [yellow]; Khasi dialect shyrmit turmeric. B: (Palaungic, ?Central Aslian) RiangLang _ramit turmeric, yellow, (or A) Central Sakai rĕmít saffron. C: (Khmer, Katuic, Khasi, Central Aslian) Old Khmer rmyat, Modern Khmer ramìat, lmìt saffron, Kuy lmìt yellow, Khasi lmet-lmet very [yellow], ProtoSemai *rmect yellow <...> (Shorto 2006: 299).

While Proto-Indo-Aryan shows some stability in differentiating between 'green' and 'yellow', this is not the case in Proto-Dravidian, cf.:

(a) Proto-Dravidian: * $p a C$ 'green, yellow; fresh, raw' > Proto-South Dravidian *pač-/*pas-, Proto-Telugu *pacc-/*pas, Proto-Kolami-Gadba *pac-/*pas, Proto-Gondi-Kui *pas;

(b) Proto-Dravidian: * $p \bar{u} c 1$ 'green' 2 'yellow' > Proto-South Dravidian * $p \bar{u} c$, Brahui pūshkun (Starostin 2006).

In some languages, the two meanings became differentiated later through additional lexical means, without the differentiation becoming obligatory, unlike in Indo-Aryan languages, cf., for instance in Telugu:

pacca I. $n .1$ greenish yellow colour; aaku green (like a leaf); pasupu yellow (like turmeric) (Gwinn 1990: 312).

Austro-Asiatic terms for 'green' are not well differentiated from 'blue' and sometimes 'yellow', cf.:

1559b *tziir; *t2ar 'blue, green'. A: (South Bahnaric, Khasi) Biat exr 'yellow'; (*t[l]2iir >) Sre talir 'blue, green' $(\rightarrow$ Röglai), Khasi lir 'blue, indigo' (compounding form?). B: (South Bahnaric, Khmuic) Biat $p r$ 'green', Thin 2ŭr 'blue' (Shorto 2006: 416);

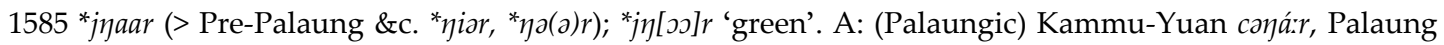
yiar, nər, Riang-Lang _yer, Lawa saya 'green', Khasi [im] ngarngar 'very [green, unripe]'. B: (Khmuic, Ni- 


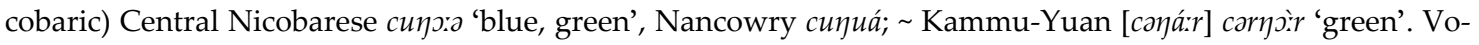

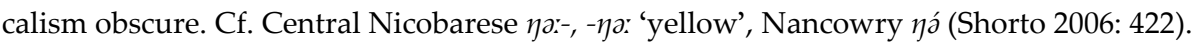

My interpretation of Eastern Indo-Aryan innovations in colour terminology is as follows: when native Munda and Dravidian speakers of East India began switching to Indo-Aryan dialects en masse, the unusual colour designation for 'yellow' was replaced by a calque, based on the meaning 'turmeric'. At the same time, a separate colour designation for 'green' was lost until the era of mass borrowings from Persian in the Middle Ages, when a Persian name was introduced for this colour. In the preserved Dravidian and Munda languages, new descriptional colour designations for 'green' were occasionally developed. These designations were derivatives from or words coinciding with the names of natural objects, such as the leaf or a weed (exactly, Hydrilla verticillate). Since then, small Indo-Aryan idioms of South Odisha, under the influence of Munda and Dravidian languages of the substrate, have also developed new calque-based colour designations for 'green', based on natural objects. Thus, this is an example of mutual influence between language families, which occurs in several stages. For Konkani, I can suggest that the word for 'yellow' was replaced by halduve under South Dravidian semantic influence, and that later the descendant of harita 'green' was replaced by a Dravidian loanword because of phonetic closeness of the original word for 'green' to the new word for 'yellow'.

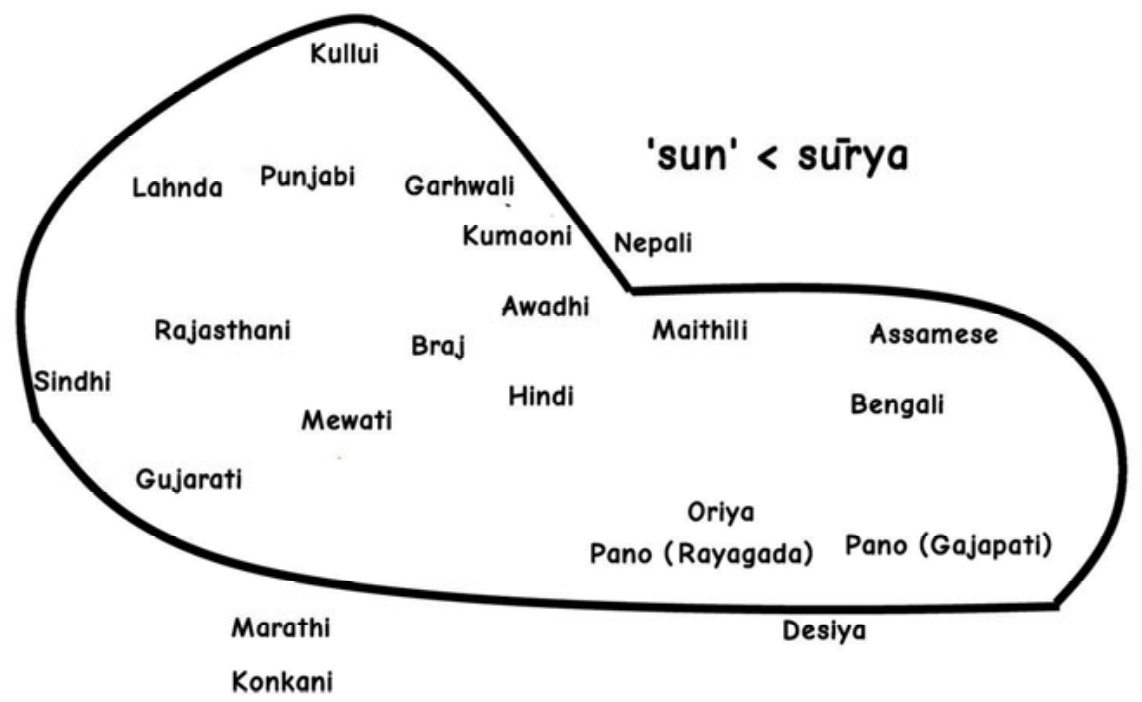

Figure 6. Descendants of sūrya 'sun' with the same meaning

The next example to be examined refers to the meaning 'sun'. In the vast majority of Modern Indo-Aryan languages, the main term for 'sun' goes back to Proto-Indo-Aryan sūrya/sūriya (Fig. 6), although it has many synonyms, primarily Sanskritisms.

However, we can see that in Desiya the lexeme bel is used with the same meaning. It is obviously related to Kui bela with the same meaning. However, the root is widely represented in various Indo-Aryan languages, as reported in Turner's dictionary:

12115 vếlā f. 'limit, boundary, time’ ŚBr., ‘flood tide’ MaitrUp., 'shore, opportunity’ MBh. 2. *vēdāa. $3 .{ }^{*} v \bar{u} l \bar{\imath}$ 'tide, time'. [ $d$ appears in K. and Or. and poss. in cmpd. *ardhavēda. In N. Mth. Bhoj. Aw. H. forms with $r$ could derive from $d$, but more prob. represent the EH., Bi. or Mth. change of $l>r$. But the forms of véla and *savēla with -r-<-> occurring in P. Ku. G. M. (as well as those already mentioned) may be from an old *vērā $~$ vélā rather than all be loans from the East Hindi Bihari area.<...> 1. Pa. vēlā f. 'shore, time'; NiDoc. velammi 
loc. sg. m. 'time' (yamvela 'when', tamvela 'then'); Pk. vēlā f. 'shore, tide, time, opportunity' (whence vēlāvaï 'is late'); Ash. Wg. Kt. wēl 'time, season, year'; Sh. bĕl, bil (following pres. part.) 'at the time of'; K. vil f. 'short space of time', vēla m. 'time, hour'; S. vera $\mathrm{f}$. 'time, delay', veri $\mathrm{f}$. 'time, turn'; L. vel $\mathrm{f}$. 'leisure', velā m. 'time'; P. vel f. 'length of an animal', velā, be $e^{\circ}$. 'time' (ber f. 'time' $\leftarrow$ H.), bhaț. us weẹte 'then', ik bēri 'once'; WPah.bhal. án belū 'untimely', cam. bèr 'delay'; Ku. bel f. 'meal fixed for a time, food taken at one time, meal', ber 'time'; N. ber 'time'; A. beli 'time, turn, year'; Or. bela 'daytime', 'le 'once during the day', '? $\tilde{u}, ~ ' ? u$ 'from the beginning'; Mth. beri 'time', beriā 'afternoon'; Bhoj. bēr 'time'; OAw. bera f. 'time, turn', lakh. bēr; H. ber f. 'limit, season, time', biriyã f. 'space of time'; G. vel f. 'time’; M. vel, el f. 'seashore', m.f. 'time, leisure, half day'; Ko. velu 'time'; Si. vel a 'seashore, sandbank' <...> (Turner 1966: 702).

However, the meaning of this word, as a rule, is not 'sun', but rather 'time span', 'daytime'. Exceptions are found in the Eastern Indo-Aryan languages Assamese and Oriya, in which one of the meanings is precisely 'sun': Oriya bel 'time, time or half part of day, the sun' (Praharaj 1931-1940: 5902), Assamese beli 'time, the sun, turn, year, delay’ (Candrakānta 1962: 700).

Of course, this term is not the most widely used, thus it is not found in the basic wordlist. In general, the polysemy 'time/sun' is not widespread among Indo-Aryan languages, and in Sanskrit vela does not mean 'sun', but 'limit', 'boundary', 'period of time' etc. On the contrary, in Dravidian languages such a polysemy is very common, cf.:

3774 Ta. nēram time, season, opportunity. Ma. nēram sun, day, light, time, season, hour, turn; nērattu early, seasonably. Koḍ. ne'ra sun, time; ne'rate early in the morning. Tu. nērdè id. Br. dē sun, sunshine, day, time (Burrow \& Emeneau 1984: 337).

However, the word vela 'sun, time' in Dravidian languages is represented only at the Gondi-Kui level, cf.: 'sun' - Konda podu $1<\ldots>$ Cf. also ve:la, with polysemy: 'sun/time' <...> (Sova dialect variant: ve:ra); Pengo ve:ra ${ }^{2}<\ldots$. . Polysemy: 'sun/time'; Manda ve:ra ${ }^{2}<\ldots>$ Polysemy: 'sun/time/period/daytime/season'; Kui ve:la ${ }^{2}<\ldots>$ Polysemy: 'sun/time/hour/ occasion/season'. Balliguda dialect: be:la 'moment, time' $\langle\ldots$. , but the meaning 'sun' comes out in compounds, e.g. be:la pe:nu 'sun deity', etc.; Kuwi ve: $a^{2}<\ldots>$ Polysemy: 'sun/age'. Sunkarametta, Parja: ve: $\{a$ 'sun' <...> Additionally, cf. also ga:ma <...>, with polysemy: 'sun/ perspiration' (Starostin 2001-2019).

Since it is not represented in other Dravidian groups, we can assume the word to be a local borrowing from Indo-Aryan languages. At the same time, the meaning 'sun', which became its main meaning in Desiya, and its secondary meaning in Oriya and Assamese, probably developed in Eastern Indo-Aryan languages under the influence of Dravidian.

Another possible substrate phenomenon that we may have been able to come across is the word for 'woman', derived from the word 'mother' in Desiya and Pano: mai, maiji. A similar

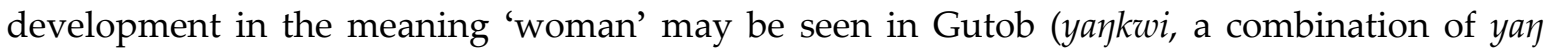
'mother' with the feminizing suffix kwi).

Cf. similar semantic shifts in Mon-Khmer languages:

113 *[2]bo? 'mother'. A: (Mon, Viet-Mương, North \& Central Aslian) Old Mon 'bo' /mbuz/ 'mother', Modern Mon $b_{32}$ 'female of animals' $<\ldots>$, Jehai $b$, Temiar bo:? 'mother'; probably $\rightarrow$ Malay $i b u, \rightarrow$ Javanese $i b u$; Mương $b o ̣$ < $<>$ Vietnamese $v o ̣$ 'wife', Semnam babo:? 'wife, woman', Jehai babo?, Temiar babo:? 'woman'. Or * $m b$ - (Shorto 2006: 96).

However, in this case, I do not have sufficient data to make any strong conclusions.

In addition to the abovementioned cases, there are cases of less easily explicable areal substitutions in East Indo-Aryan languages, some of which need to be examined in more detail. 


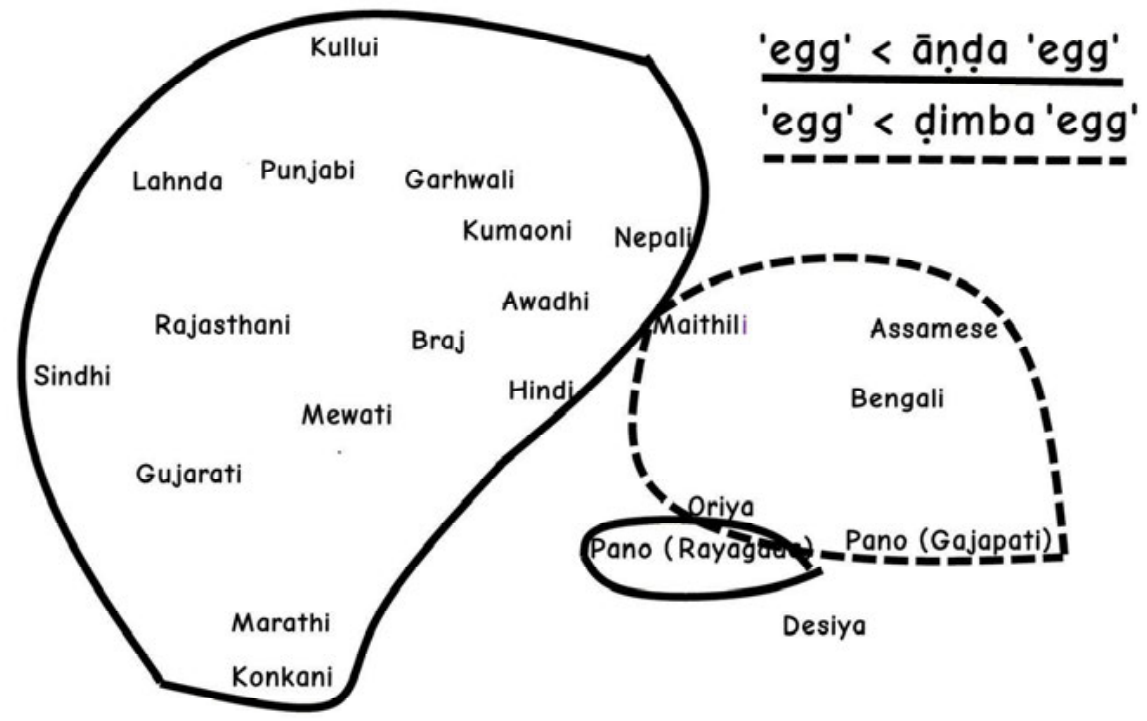

Figure 7. The origin of the words for 'egg' in 110-item wordlists of Indo-Aryan languages.

For example, in most Indo-Aryan languages the meaning 'egg' is expressed by descendants of Old Indian ānda, while in Bengali, Assamese, Oriya and Maithili it is developed from dimba: Assamese dima, Bengali, Oriya dim, Maithili dìm (Fig. 7). Curiously, Proto-Indo-Aryan ānda is associated with the polysemy 'egg/testicle', while dimba is associated with the polysemy 'egg/ foetus' polysemy, which brings it closer to the Proto-Dravidian term *karb- 'egg, foetus':

Proto-Dravidian : *karb- 'egg, foetus' > Proto-South Dravidian : *karu- 'foetus' (Tamil karu 'foetus, embryo, egg, germ, young of animal', karuppai 'womb', karuvam 'foetus, embryo', Malayalam karu 'embryo, yolk', karuntala 'generation', Kannada kandu 'foetus of beasts'), Proto-Telugu *karv- 'foetus' (Telugu karuvu, also kari 'uterus of animals', karugu 'an unopened ear of corn'), Proto-Kolami-Gadba *karb- (Parji, kerba, pl. kerbel 'egg', Ollari Gadba karbe 'egg'), Proto-Gondi-Kui *garb- 'egg' (Proto-Gondi *garb- 'egg' > Koya Gondi garba, Su. garbūm) (Starostin 2006).

Although some of the listed Dravidian forms, contrary to the etymology, seem to have been borrowed from Old Indian garbha 'foetus' (Koya Gondi, etc.), others are more likely to represent an inherited item, or, at least, the results of contamination between an inherited root and the phonetically and semantically similar Indo-Aryan item. We can therefore suggest the polysemy 'egg/foetus' for the Proto-Dravidian level.

Among the 110-item wordlists that I have personally analyzed, this root is represented by Kui garbay 'egg' and by the Dravidian borrowing gar 'egg' in Desiya. As to the descendants of Proto-Indo-Aryan dimba, it can be suggested that Dravidian influence may have been behind the choice of root in the basic lexicon.

The meaning 'knee' presents another example of this kind. Thus, the descendants of Proto-Indo-Aryan godda 'ankle' with the meaning 'knee' are common in the middle part of the Indo-Aryan region, but not in the east, where the descendants of Proto-Indo-Aryan așthīoát 'knee' dominate (Fig. 8). In Desiya, however, they are replaced by another Dravidian loan, mandi ' $k$ nee'. Moreover, Dravidian mandi is borrowed into all the Munda languages in the micro-area under study (Sora, Bonda, Dideyi and Gutob).

To conclude, it is extremely important to pay attention to the influence of substrate on basic vocabulary in the case of a language area, since the semantic shifts which occurred under this influence, may have a critical effect on evaluating the degree of genetic relationship between 


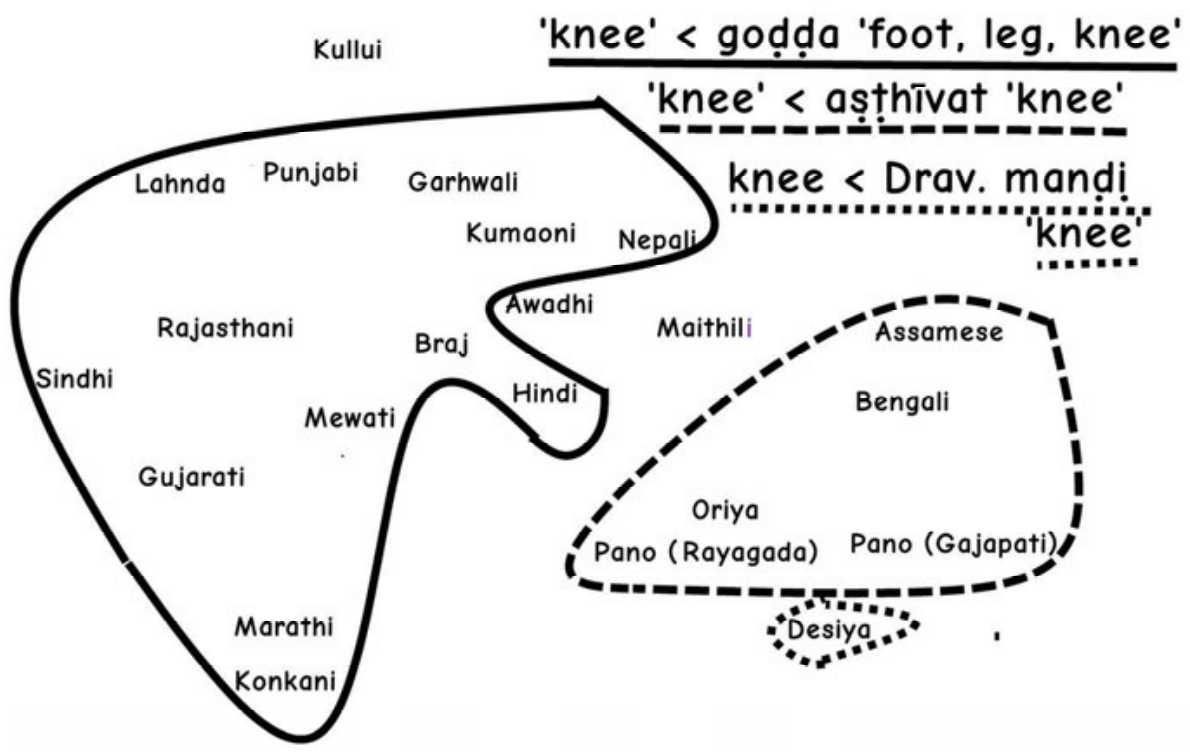

Figure 8. Origins of the words for 'knee' in 110-item wordlists of Indo-Aryan languages.

languages. Here, we can see how Eastern and Southern Indo-Aryan languages show some cases of replacement of words from basic vocabulary by another primordial words under Dravidian and Munda influence. In South Odisha, the area of very close communication between speakers of three language families, such substitutions are observed imediately in real time.

Additional materials for the paper (maps) are available in the online Supplement at: http://jolr.ru/jlr11/krylova.zip

\section{References}

Burrow, Thomas, M. B. Emeneau. 1984. A Dravidian etymological dictionary. 2nd ed. Oxford: Clarendon Press.

Dybo, Anna V. 2013. Etimologicheskij slovar' tyurkskih yazykov. Tom 9 (dopolnitel'nyj): Etimologicheskij slovar' bazisnoj leksiki tyurkskih yazykov. Astana.

Gwynn, John P. L. 1991. A Telugu-English dictionary. Delhi/New York: Oxford University Press.

Kassian, Aleksei, George Starostin, Anna Dybo, Vasily Chernov. 2010. The Swadesh wordlist. An attempt at semantic specification. Journal of Language Relationship 4: 46-89.

Kogan, Anton. 2016. Genealogical classification of New Indo-Aryan languages and lexicostatistics. Journal of Language Relationship 14: 227-258.

Krylova, Anastasia. 2017. Lexicostatistics and the New Indo-Aryan languages. Journal of Language Relationship 15: 279-298.

Normanskaya, Yuliya V. 2005. Genezis i razvitie sistem cvetooboznachenij v drevnih indoevropejskih yazykah. Moskva: Institut jazykoznanija RAN.

Pinnow, Heinz J. 1959. Versuch einer historischen Lautlehre der Kharia-Sprache. Wiesbaden: Harrassowitz.

Praharaj, Gopal C. 1931-1940. Purnnacandra Odia Bhashakosha. Cuttack: Utkal Sahitya Press.

Shorto, Harry. 2006. A Mon-Khmer comparative dictionary. Canberra: Pacific Linguistics.

Turner, Ralph L. 1966. A comparative dictionary of Indo-Aryan languages. Oxford University Press.

Starostin, George. 2006. Dravidian Etymological database. Available online at: http://starling.rinet.ru [Accessed 07.11.2018].

Starostin, George (ed.). 2011-2019. Global Lexicostaristical database. Available online at: http://starling.rinet.ru/ new100 [Accessed 07.11.2018].

Vitebsky, Piers. 2017. Living Without the Dead: Loss and Redemption in a Jungle Cosmos. Chicago/London: The University of Chicago Press.

Sidwell, Paul (ed.). 2009-2011. Munda Languages Database. Available online at: http://sealang.net [Accessed 07.11.2018]. 
А. С. Крылова. Ареальные особенности 110-словного списка по индоарийским языкам Южной Ориссы

Основной темой статьи является проблема замены исконных слов, относящихся к базисной лексике, под влиянием языковых контактов между индоарийскими, дравидийскими и мунда языками в Южной Ориссе и Восточной Индии в целом. Помимо заимствований, особое внимание уделяется случаям неочевидного контактного влияния субстрата в индоарийских языках, когда исконное слово заменяется на другое исконное в результате семантического сдвига, характерного для другой языковой семьи. Рассмотрение таких изменений критически важно для лексикостатистических подсчётов.

Ключевые слова: индоарийские языки; дравидийские языки; мунда языки; базисная лексика; лексикостатистика; ареальная лингвистика. 